\title{
On the definition of Tapeinini, and description of a new genus and species (Coleoptera, Cerambycidae)
}

\author{
Antonio Santos-Silva (1) \& Francisco E. de L. Nascimento (1)
}

LAC- Laboratório de Coleoptera, Museu de Zoologia, Universidade de São Paulo, São Paulo, SP, Brazil, 04263-000 (†oncriss@gmail.com; eribnascimentofl@gmail.com)

Received 25 February 2019

Accepted 23 May 2019

Published 15 July 2019

DOI 10.1590/1678-4766e2019023

ZOOBANK urn:Isid:zoobank.org:pub:CDD35D60-6B86-4A7C-A9C8-CCF781224E8C

ABSTRACT. The definition of Tapeinini is discussed. A new genus with a new species, Wappesicus wappesi is described from Bolivia in Acanthoderini. Tapeina rudifrons Marinoni, 1972 is illustrated and its geographic distribution updated.

KEYWORDS. Brazil, Neotropical region, taxonomy, Lamiinae.

SANTOS-Silva \& NASCIMENTO (2018) called attention to the chaotic taxonomic status of some genera in Lamiinae (Cerambycidae) and to the problematic delimitation of its tribes, especially Acanthoderini and Desmiphorini. Through the study of both, new and already described species, it is possible to see the fragility of the limits between those two tribes, as defined by some authors (e.g. LACORDAIRE, 1872; LiNSLEY \& CHEMSAK, 1985).

Herein, the definition of Tapeinini Thomson, 1857, and the problematic status of Acanthoderini and Desmiphorini are discussed. New taxa and new distributional records are also provided.

\section{MATERIALS AND METHODS}

Photographs were taken in the MZSP with a Canon EOS Rebel T3i DSLR camera, Canon MP-E 65mm f/2.8 1-5X macro lens, controlled by Zerene Stacker AutoMontage software. Measurements were taken in " $\mathrm{mm}$ " using a measuring ocular Hensoldt/Wetzlar - Mess 10 in the Leica MZ6 stereomicroscope, also used in the study of the specimens.

The acronyms used in the text are: ACMT, American Coleoptera Museum, San Antonio, Texas, USA(James Wappes); FSCA, Florida State Collection of Arthropods, Gainesville, Florida, USA (Paul E. Skelley); MZSP, Museu de Zoologia, Universidade de São Paulo, São Paulo, Brazil (Sônia Casari).

\section{RESULTS}

Tapeinites Thomson, 1857:41.

Tapeinitae; ThOMson, 1860:73.

Tapeininae; PASCOE, 1864:9.

Tapeinini; BATES, 1881:191.
According to MARINONI (1972) (translated): "Thomson, Bates, and Breuning related Tapeinini with Desmiphorini, while Serville, Laporte and Lacordaire indicated its relationship with Enicodini." However, this statement is not entirely true. THOMsON (1857) only reported that (translated): "it would be difficult, in the present state of the classification of Cerambycids, to assign to the Tapeinites a place other than among the Lamiites." THOMSON (1860:349) did not provide a clear relation between Tapeinini and Desmiphorini, however, the author demonstrates a certain similarity of both with old-world groups (translated): "It is incontestable that Enicodes attaches the Tmesisternites to the Saperdites by Desmiphorites, and especially by the Tapeinites... It can therefore be said that the Tmesisternites must be placed between the Saperdites and the true Lamiites." In the same work, THOMson (1860:71) by discussing on Desmiphoritae stated (translated): "Tapeinitis: 1, frons in male unarmed; 2, prothorax laterally spinose, different." THOMSON (1864-1865) did not provide details on his insinuated relationship between Tapeinini and Desmiphorini.

According to BATES (1866): “This group was placed provisionally under the Saperditae, in the synopsis previously given of the Lamiaires. A more accurate examination has convinced me that it has closer affinities with the members of the Desmiphoritae. The Tapeinae, in fact, appear to be abnormally flattened forms of Exocentrinae." Currently, Exocentrini is a synonym of Pogonocherini. MonNÉ (2018) listed Exocentrini in the synonymy of Acanthocinini (however he neglected to remove the old synonymy with this tribe) and Pogonocherini, Bouchard et al. (2011) listed it in the synonymy of Pogonocherini, and TavakiLIan \& Chevillotte (2018) considered Exocentrini as a distinct tribe (apparently, ignoring the synonymy proposed by SAMA, 
2008). Subsequently, BATES (1881) changed his opinion: "I am now inclined to doubt that Tapeina has any close affinity with the Exocentrini, the anterior acetabular sutures being less tightly closed than they are in the true members of that group; and I think their true place is near Eupogonius and allies in the Desmiphorini." BREUNING (1950) indicated, at least, the proximity of Tapeinini and Desmiphorini. AUDINETSERVILle (1835) and LACORDAIRE (1872) really considered Tapeina Lepeletier \& Audinet-Serville, 1828 and Enicodes Gray, 1832 close to or related to each other. LAPORTE (1840) listed Eurycephalus Gray, 1831 and Enicodes as synonym of Tapeina.

Still according to MARINONI (1972) (translated): "All the characters that are common to Tapeina and Peritapnia, also are common to the genera of Acanthoderini, such as: ... mesocoxal cavities closed." However, in the redescription of Tapeina, he reported (translated): "Mesepimeron enters the coxal cavity." But this latter information is incorrect, because the mesocoxal cavities are closed, although the posterior angle of mesoventrite does not touch the anterior angle of the metaventrite (this shape of mesocoxal cavity more common in Desmiphorini than in Acanthoderini).

The main problem to correctly allocate Peritapnia Horn, 1894, Tapeina, and Wappesicus gen. nov., is to understand the definition of Acanthoderini, Desmiphorini (including Estolini), and Pogonocherini, without mentioning several other tribes not occurring in the American continent. LINSLEY \& CHEMSAK (1985) provided a key separating these three tribes. However, nearly all features used to separate them are only useful when studying North American genera, which makes the definitions of the tribes both incomplete and inaccurate. In that key, the first step where these tribes were separated is the alternative of couplet "13": "Antennae with scape clavate", leading to Acanthoderini; "Antennae with scape cylindrical or conical", leading to Desmiphorini, Pogonocherini, and Estolini. This is problematic as there are genera in Acanthoderini with the scape not or only very slightly clavate, such as Exalphus Restelo et al., 2001 and Pycnomorphidiellus Tavakilian \& Peñaherrera-Leiva, 2003; or genera with the shape of the scape very variable, from distinctly clavate to distinctly not clavate, as for example in Oreodera Audinet-Serville, 1835. In the same way, Pogonocherini were separated from Estolini (currently equal to Desmiphorini) as follows: "Body short and convex, long flying hairs often present, if elongate and flying hairs absent, pronotum laterally unarmed", leading to Pogonocherini; "Body elongate and parallel-sided, flying hairs absent; pronotum tuberculate laterally", leading to Estolini. A study of the genera currently included in Desmiphorini indicates that the body shape, presence or absence of long setae and/ or tubercle on sides of prothorax are useless as characters to separate the Desmiphorini from Pogonocherini, except for North America genera. The same problem occurs with nearly all tribes of Lamiinae because, their definitions are usually based on local genera.

When defining Acanthoderini, LINSLEY \& CHEMSAK (1985) affirmed: "This tribe may be recognized by the clavate scape of the antennae, prominent lateral tubercles of the pronotum, short stout body form, almost separated eyes, clavate femora and by the fringed front tarsi of the males of most genera." The lateral tubercles of the prothorax may be very small, as in Amblysaphes Bates, 1885, or only a rounded protuberance as in Mundeu Martins \& Galileo, 2008; and the body shape, and distance between upper and lower eye lobes, and femoral shape are all noticeably variable in Acanthoderini.

Sama (2008) reported: "The tribe Exocentrini Pascoe, 1864 is usually regarded as a synonym of Acanthocinini (Aurivillius, 1923, Breuning, 1962). Exocentrus differ from palaearctic Acanthocinini by the characteristic shape of the last segment of the abdomen of females: the last two tergites are internally divided by a longitudinal, cartilaginous apodeme, beginning as a narrow lamina from the middle of the $4^{\text {th }}$ sternite and ending at the apex of the 5th where it is enlarged laterally. As written above an analogous structure exists in Ceroplesis and Crossotus (Ceroplesini) as well as in other genera of Laminae [sic] such as Idactus Pascoe, 1864 (Ancylonotini), Sophronica (Apodasyini) and Pogonocherus (Pogonocherini), and never in Acanthocinini. Exocentrus and closely related genera and subgenera must be consequently transferred to the tribe Pogonocherini. According to Švácha (pers. comm.), this systematic change is supported by the immature stages morphology." We do not know if this feature is really absent in all Acanthocinini but, probably it is another variable character. Even larval features, often indicated as differential for Acanthocinini, have been revealed as only generic variations (Sônia Casari, pers. comm.). We agree with SAMA (2008) that the existence of Exocentrini is incorrect, but a reliable feature that allows separating Pogonocherini, Desmiphorini and Acanthoderini has not been found. According to NASCIMENTO et al. (2019): "LACORDAIRE (1872) included Desmiphorini among the tribes with mesocoxal cavities open laterally, and Pogonocherini, Acanthocinini and Acanthoderini among the tribes with mesocoxal cavities closed laterally. However, the mesocoxal cavities in all genera of Desmiphorini examined by us are exactly as in the Pogonocherini and Acanthocinini: closed laterally (mesoventrite not touching metaventrite)." These authors concluded that all genera currently placed in Pogonocherini may be included in Desmiphorini and/or Acanthoderini.

The main arguments of MARINONI (1972) to include Peritapnia in Acanthoderini and to keep Tapeinini as a distinct tribe are (translated): “... Peritapnia has in common with Acanthoderini and not with Tapeina: the anterior border of the first abdominal sternum narrowly inserted between the posterior coxae and scape piriform. Plus, the intercoxal processes is narrow, convex and in a plane much higher than the anterior portion of the respective sternum." However, there are several problems with these statements. Firstly, the abdominal process is not narrow in Peritapnia (Figs 2, 6) as suggested. Rather, it is or may be very similar to that of Tapeina (Figs 10, 14). As previously mentioned, the scape in Acanthoderini is very variable and frequently, it is not piriform. Although the prosternal process and mesoventral process are wide in Tapeina (always wider than coxal cavity), 
it is more variable in Peritapnia, and although it is always narrower than coxal cavity, it may be distinctly narrower or wider than half of the coxal cavity. Furthermore, the central area of the prosternal process in the new genus described here is slightly narrower than procoxal cavity, and the narrowest area of the mesoventral process is as wide as mesocoxal cavity. The "plane" of the intercoxal processes is variable in Peritapnia, but can be similar to that in Tapeina. For example, CHEMSAK \& LinSLEY (1978) reported on their new species $P$. minima: “... intercoxal process [prosternal process] almost plane..." Finally, the new genus has features of Tapeina and Peritapnia: scape similar to Peritapnia; lateral tubercles of the prothorax acute at apex as in Peritapnia (rounded in Tapeina); intercoxal processes similar to Tapeina; meso- and metafemora nearly fusiform as in Tapeina (pedunculateclavate in Peritapnia); and abdominal process more similar to Peritapnia (slighter wider in Tapeina, but not so wide as suggested by MARINONI, 1972).

Based on the lack of reliable features, and especially by the existence of Wappesicus gen. nov., which clearly have intermediate features between Tapeina and Peritapnia, would be evident the synonymy, based on the characters currently proposed for Acanthoderini and Tapeinini. However, it is possible that Tapeina (Figs 9-18), Peritapnia (Figs 1-8), and the new genus (Figs 19-22) belong to Desmiphorini because the imperfectly closed mesocoxal cavities (mesoventrite not touching metaventrite), is much more common in this tribe than in Acanthoderini. Nevertheless, as indicated, this feature is variable in the species (not only genera) currently placed in those tribes. Thus, as it was not possible to know what defines and separates Acanthoderini and Desmiphorini, it is not possible to establish a synonymy with security. However, the understanding of the true separation between Acanthoderini and Desmiphorini will only be possible after an embracing study of all genera including in them, not only base in genera of a particular area of the World, as has been done, but including genera from several places. We are being conservative and including the new genus in Acanthoderini, due to the current inclusion of Peritapnia in this tribe.

\section{Wappesicus Santos-Silva \& Nascimento, gen. nov.}

Etymology. Latin, sufix “-icus" (belonging to), added to the surname of James E. Wappes. Masculine gender.

Type species. Wappesicus wappesi sp. nov., here designated.

Description, female. Body moderate-sized, flattened. Head not retractile; frons transverse, not forming transverse plate, slightly convex close to clypeus, V-shaped, centrally depressed toward vertex. Gena distinctly shorter than lower eye lobe. Eyes coarsely faceted; distance between upper eye lobes distinctly larger than twice width of one upper eye lobe. Outer side of mandibles with large triangular depression, with its apex surpassing middle of mandible. Last maxillary and labial palpomeres gradually narrowed toward apex. Antennal tubercles not forming plate laterally on scape ball. Antennae filiform, shorter than body; scape longer than antennomere III, slightly piriform, not reaching middle of prothorax; antennomeres III and IV subequal in shape and length. Prothorax transverse, with distinct, wide posterior constriction; sides strongly divergent from anterolateral angles to acute lateral tubercle, then strongly convergent toward base of posterior constriction. Procoxal cavities closed posteriorly. Prosternum slightly transversely sulcate near base of prosternal process. Prosternal process wide, with narrowest area slightly narrow than procoxal cavity, very slightly more elevated than surface of prosternum, strongly widened from middle toward apex, which is laterally lobeshaped, and with posterior margin widely concave; posterior half inverted V-shaped depressed centrally. Mesoventral process wide, moderately narrowed centrally (narrowest area about as wide as procoxal cavity). Mesocoxal cavities closed, but with apex of mesoventrite distinctly not touching apex of metaventrite. Scutellum proportionally small, posteriorly rounded. Elytra slightly longer than 1.5 time humeral width; parallel-sided from humerus to slightly after middle, then gradually, round narrowed toward sutural angle. Femora fusiform. Abdominal ventrite $\mathrm{V}$ strongly inverted, V-shaped and centrally depressed, with distal margin of this area narrowly elevated (plate-shaped).

Remarks. Wappesicus gen. nov. is similar to Peritapnia but differs as follows: prosternal and mesoventral processes nearly as wide as the pro- and mesocoxal cavities (Fig. 21); scape more elongate, not distinctly piriform (Figs 19, 20); femora fusiform (Fig. 21). In Peritapnia, the prosternal and mesoventral processes are distinctly narrower than procoxal cavities (Figs 2, 7), scape distinctly piriform (Figs 4, 8), and the femora are pedunculate-clavate (Figs 2, 6). Wappesicus gen. nov. differs from Tapeina by the antennae (Fig. 20) shorter than body [longer (Fig. 18) in female of Tapeina], scape slightly piriform, not reaching middle of prothorax [cylindrical (Fig. 18), reaching middle of prothorax in Tapeina], and prothorax (Fig. 20) with acute lateral tubercle [rounded (Fig. 18) in Tapeina].

\section{Wappesicus wappesi Santos-Silva \& Nascimento, sp. nov.} (Figs 19-22)

Description, female. Head dark mostly reddish brown; narrow area surrounding eyes, distal area of genae, distal area of postclypeus, and median groove on frons dark brown; gulamentum reddish brown, gradually lighter toward posterior area; antennae dark reddish brown; mouthparts mostly light reddish brown, with palpomeres mostly yellowish brown; mandibles dark reddish brown on basal half, black on posterior half. Pronotum mostly dark reddish brown, narrowly dark brown anteriorly and posteriorly. Prosternum and prosternal process light reddish brown, slightly darker in sides of prosternum, with margins darkened. Central area of mesoventrite and mesoventral process light reddish brown, and sides of mesoventrite, mesanepisternum and mesepimeron dark reddish brown (margins of the ventrites narrowly darkened). Metaventrite mostly light reddish brown, 

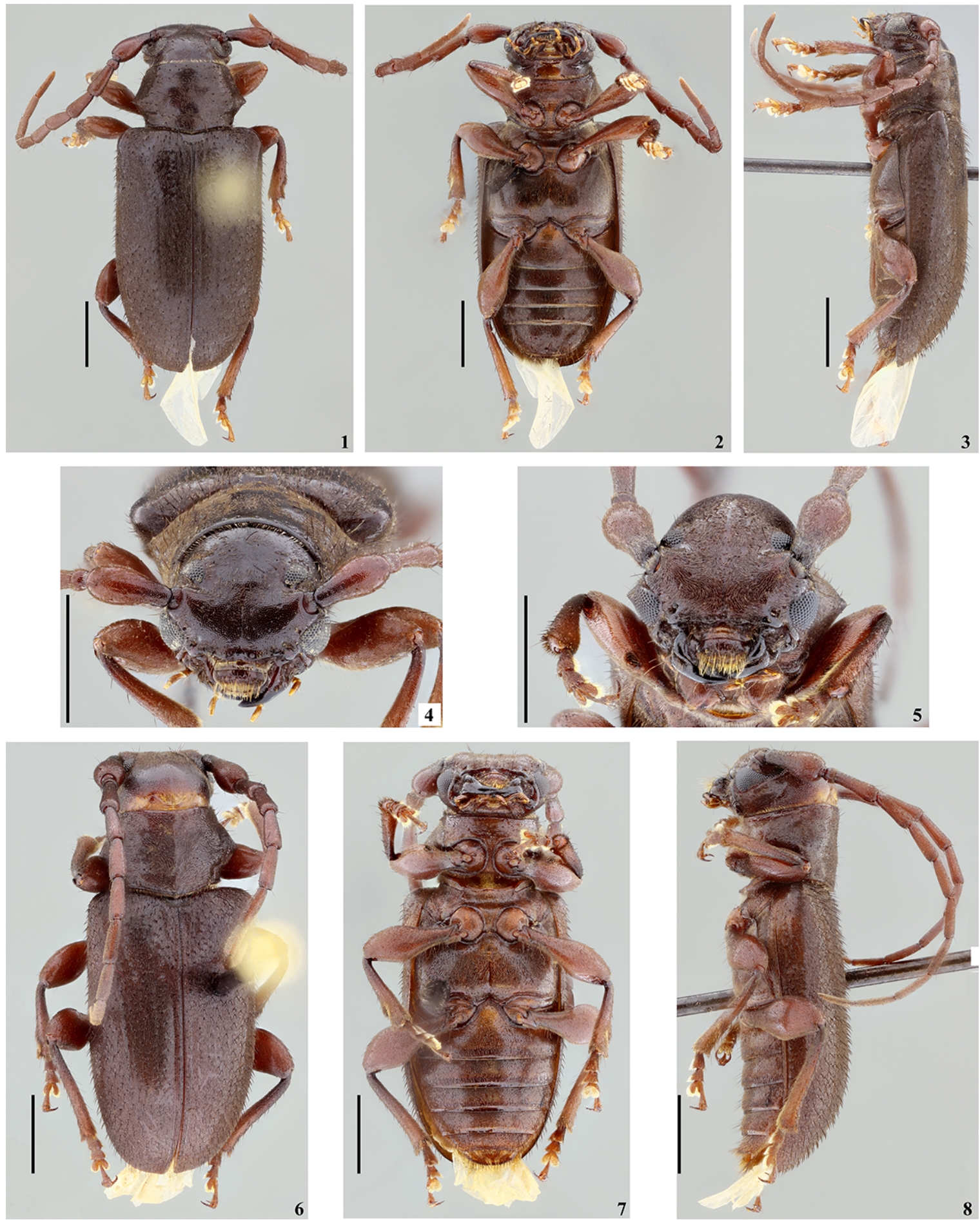

Figs 1-8. Species of Peritapnia. Peritapnia nudicornis (Bates, 1885), female: 1, dorsal habitus; 2 , ventral habitus; 3 , lateral habitus; 4 , head, frontal view. Peritapnia fabra Horn, 1894, male: 5, head, frontal view; 6, dorsal habitus; 7, ventral habitus; 8, lateral habitus. Scale bar $=2.0 \mathrm{~mm}$.

gradually darker toward sides. Scutellum reddish brown centrobasally, brown laterally. Elytra mostly dark brown, with part of sutural margin dark reddish brown. Femora mostly dark reddish brown, with darkened irregular areas. Tibiae dark brown basally, gradually dark reddish brown toward apex. Tarsi mostly dark reddish brown, with darkened irregular areas. Abdominal ventrites mostly dark reddish brown, slightly darker laterally, and dark brown on distal area of ventrites I-IV.

Head. Frons (Fig. 19) finely, abundantly punctate, with coarser punctures interspersed, from which emerges erect, long thick dark setae; with bristly, semidecumbent yellowish-brown setae not obscuring integument. Vertex with sculpturing, erect and bristly setae as on frons, area adjacent to prothorax with coarser punctures and erect setae, 



Figs 9-16. Tapeina coronata Lepeletier \& Audinet-Serville, 1828. Male: 9, dorsal habitus; 10, ventral habitus; 11, lateral habitus; 12 , head, frontal view. Female: 13 , head, frontal view; 14, dorsal habitus; 15 , ventral habitus; 16, lateral habitus. Scale bar $=2.0 \mathrm{~mm}$.

but bristly, semidecumbent yellowish-brown setae nearly absent. Area behind upper eye lobes tumid close to eye; finely, densely punctate (distinctly less so toward prothoracic margin), with slightly coarser punctures interspersed; with a few moderately long, erect, thick dark setae on tumid area; yellowish-brown pubescence adjacent to tumid area, gradually glabrous toward prothorax. Area behind lower eye lobes tumid close to eye; with sculpturing as in area 



Figs 17-22. Tapeina rudifrons Marinoni, 1972: 17, paratype female, dorsal habitus; 18, female from Bolivia, dorsal habitus. Wappesicus wappesi gen. nov., sp. nov, holotype female: 19 , head, frontal view; 20, dorsal habitus; 21 , ventral habitus; 22 , lateral habitus. Scale bar $=2.0 \mathrm{~mm}$.

behind upper eye lobes superiorly, gradually sparser toward ventral area; with bristly yellowish-brown pubescence close to upper eye lobes, gradually glabrous toward ventral side; with long, erect, thick dark setae close to eye, especially in central area. Genae minutely rugose-punctate except smooth distal area; with yellowish-brown pubescence not 
obscuring integument except glabrous smooth area; with long, erect, sparse, thick dark setae close to eye. Antennal tubercles with sculpturing, erect and bristly setae as on frons anteriorly, gradually sparsely punctate, with distinctly sparser erect and bristly setae toward posterior area. Median groove distinct on frons, slight distinct on vertex. Postclypeus narrow, transversely carina-shaped in wide central area; with long, erect, thick dark setae in wide central area (part of them gradually yellowish-brown toward apex); sides smooth glabrous. Labrum coplanar with anteclypeus in posterior third, inclined in anterior $2 / 3$, more inclined in anterior third; with short, sparse yellowish-brown setae in anterior $2 / 3$, and long, erect dark setae interspersed; with long, erect golden setae in anterior third, and fringe of dense golden setae in anterior margin. Gulamentum smooth, glabrous posteriorly; depressed finely striate-punctate, with short, sparse, erect yellowish-brown setae adjacent to anterior elevation; with sparse, long, erect, thick dark setae in anterior elevation. Distance between upper eye lobes 0.7 times length of scape; in frontal view, distance between lower eye lobes about equal to length of scape. Antennae 1.25 time elytral length, almost reaching elytral apex; with short, decumbent yellowishbrown pubescence not obscuring integument, gradually shorter, yellowish-white toward distal segments. Scape with sparse, long, erect, thick dark setae throughout. Pedicel with sparse, long, erect, thick brown setae throughout, longer ventrally. Antennomeres III-VII with sparse, long, erect brown setae ventrally, and similar setae dorsally and laterally near apex, and sparse, short, erect yellowish-brown setae throughout. Antennomeres VIII-X with sparse, long, erect brown setae near apex, and sparse, short, erect yellowishbrown setae throughout. Antennomere XI with sparse, short, erect yellowish-brown setae throughout. Antennal formula (ratio) based on length of antennomere III: scape $=1.40$; pedicel $=0.47 ; \mathrm{IV}=1.03 ; \mathrm{V}=0.97 ; \mathrm{VI}=0.94 ; \mathrm{VII}=0.94$; $\mathrm{VIII}=0.90 ; \mathrm{IX}=0.90 ; \mathrm{X}=0.90 ; \mathrm{XI}=1.09$.

Thorax. Pronotum moderately tumid in anterior 2/3 (except narrow area close to anterior margin), with one wide, subcircular, slightly elevated gibbosity each side, and one elongate gibbosity centrally, nearly fused with lateral ones; minutely, abundantly punctate, with coarser punctures interspersed (absent in lateral gibbosities), except smooth central gibbosity; with yellowish-brown pubescence not obscuring integument, except glabrous central gibbosity; with long, erect, thick, dark setae emerging from part of coarser punctures (Fig. 20). Sides of prothorax with yellowish-brown pubescence not obscuring integument, with sparse, long, erect dark setae (shorter than in pronotum). Prosternum minutely, sparsely punctate centrally, slightly striatepunctate laterally; with sparse, short, decumbent yellowish pubescence, slightly more abundant laterally, with long, erect, dark setae interspersed. Prosternal process with yellowish pubescence as on central area of prosternum, with long, erect, thick dark setae basally and close to lateral margins, not reaching distal area. Ventral surface of mesothorax with yellowish pubescence not obscuring integument, with sparse, long, erect, thick dark setae in sides of mesoventrite and lateral margins of mesoventral process. Ventral surface of metathorax with yellowish pubescence not obscuring integument, sparser toward central area of metaventrite; with sparse, long, erect, thick dark setae in sides and posterocentral area of metaventrite, and sparse, long, erect yellowish setae laterally (Fig. 21). Scutellum with sparse yellowish-brown setae, forming fringe with denser setae along margins (longer toward centrodistal apex). Elytra coarsely, abundantly punctate throughout; with short, decumbent yellowish-brown pubescence not obscuring integument, with abundant, long, erect, thick dark setae throughout (Fig. 22); erect setae not emerging from the punctures. Legs: femora and tibiae with abundant yellowish pubescence not obscuring integument, with long, erect, thick, dark setae interspersed.

Abdomen. Ventrites minutely, abundantly punctate, with coarser punctures interspersed; with yellowish pubescence not obscuring integument; with long, erect, thick, dark setae emerging from coarser punctures. Ventrite $\mathrm{V}$ triangularly depressed posteriorly.

Dimensions (mm). Total length, 8.50; prothoracic length, 1.60; anterior prothoracic width in anterior constriction, 1.75; anterior prothoracic width before anterior constriction, 2.10; posterior prothoracic width, 2.05; maximum prothoracic width, 2.85; humeral width, 3.60; elytral length, 6.00.

Type material. Holotype female from BOLIVIA, Santa Cruz: $20 \mathrm{~km}$ N Camiri Rd to Eyti (6.8 km E Hwy 9; $\left.1250 \mathrm{~m} ; 1^{\circ} 52^{\prime} \mathrm{S} / 63^{\circ} 29^{\prime} \mathrm{W}\right), 8-9 . X I I .2015$, Wappes, Kuckartz and Skillman col. (FSCA, formerly ACMT).

Etymology. The new species is dedicated to our friend James E. Wappes (ACMT).

\section{Tapeina rudifrons Marinoni, 1972}

(Figs 17, 18)

Tapeina rudifrons MARINONI, 1972:30; ZAJCIW, 1974:72 (distr.); MARINONI et al., 1992:111 (paratype); Monné, 1994:49 (cat.); MonnÉ \& GIESBERT, 1994:183 (checklist); Julio et al., 2000:50 (holotype); Di Iorio, 2004:54 (distr.); Monné, 2005:649 (cat.); Monné \& Hovore, 2006:297 (checklist); WAPPES et al., 2006:24 (distr.); MARTINs et al., 2011:291 (distr.); WAPPES et al., 2013:12 (distr.); Monné \& Monné, 2016:73 (holotype); Moura \& vON Groll, 2017:456 (paratype); Monné, 2018:883 (cat.).

This species was originally described from Brazil (Goiás, Mato Grosso do Sul, Espírito Santo, São Paulo), Paraguay (Concepción), and Argentina (Salta, Formosa, Santiago del Estero). Di Iorio (2004) reported the species for the Paraguayan department of Alto Paraguay; WAPPES et al. (2006) recorded the species in the Bolivian department of Santa Cruz; WAPPES et al. (2013) listed it in the Bolivian department of Tarija; and MARTINS et al. (2011) recorded it in the Brazilian state of Maranhão. Originally, MARINONI (1972) listed some paratypes as being from the Brazilian state of Mato Grosso, which was true at that time. However, currently, the places where those paratypes were collected are in the Brazilian state of Mato Grosso do Sul.

We are taking this opportunity to illustrate a paratype female (Fig. 17), and another female (Fig. 18) collected 
in Bolivia. Although MARINONI (1972) had drawings of females, only a frontal view photograph of the head of a female paratype has been published.

Material examined (only the specimen from Bolivia listed) BOLIVIA, Santa Cruz: Florida (Pampagrande), 1 female, 23.XI.1995, F. A. Langer col. (ACMT).

Acknowledgments. Special appreciation to Jim Wappes for sending the specimen of the new species for inclusion in this study. To Petr Kment (Czech Republic), for important corrections in a previous version of this work. The second author is grateful for the grant 2017/15283-9, São Paulo Research Foundation (FAPESP).

\section{REFERENCES}

Audinet-Serville, J. G. 1835. Nouvelle classification de la famille des longicornes.(suite et fin). Annales de la Société Entomologique de France 1(4): 197-228.

Bates, H. W. 1866. Contributions to an insect fauna of the Amazon Valley. Coleoptera: Longicornes. The Annals and Magazine of Natural History 3(17): 191-202.

BAtes, H. W. 1881. Biologia Centrali-Americana, Insecta, Coleoptera. London, 5:153-224.

Bouchard, P.; Bousquet, Y.; Davies, A. E.; Alonso-Zarazaga. M. A.; Lawrence, J. F.; Lyal, C. H. C.; Newton, A. F.; Reid, C. A. M.; SchmitT, M.; ŚlipiŃSKI, S. A. \& SmITH, A. B. T. 2011. Family-group names in Coleoptera (Insecta). ZooKeys 88:1-972.

BREUNING, S. 1950. Considérations preliminaries sur le classication des Lamiaires. Longicornia 1: 25-28. In: LePESME, P. ed. Longicornia. Études et notes sur les longicornes. Volume I. Paris, Paul Lechevalier. $603 p$.

Chemsak, J. A. \& Linsley, E. G. 1978. New Neotropical Lamiinae (Coleoptera: Cerambycidae). The Pan-Pacific Entomologist 54(1):2630.

Di Iorio, O. 2004. Aporte al catálogo de Cerambycidae del Paraguay (Insecta, Coleoptera). Parte IV. Addenda a Bosq (Partes I y II) y Viana (Parte III). Boletín del Museo Nacional de Historia Natural del Paraguay 15(1-2):9-65.

Julio, C. E. A.; Giorgi, J. A. \& Monné, M. A. 2000. Os tipos primários de Cerambycidae (Coleoptera) da coleção do Museu Nacional - Rio de Janeiro. Publicações Avulsas do Museu Nacional 84:1-54.

Lacordaire, J. T. 1872. Histoire Naturelle des Insectes. Genera des Coléoptères, ou exposé méthodique et critique de tous les genres proposés jusqu'ici dans cet ordre d'insectes. Vol. 9(2). Paris, Librairie Encyclopédique de Roret, p. 411-930.

LAPORTE, F. L. N. 1840. Histoire Naturelle des Insectes Coléoptères avec une introduction renfermant l'anatomie et la physiologie des animaux articulés, par M. Brullé; ouvrage accompagné de 155 planches gravées sur acier représentant plus de 800 sujets. Vol. 2. P. Paris, Duménil. 563p.

Linsley, E. G. \& Chemsak, J. A. 1985. The Cerambycidae of North America. Part VII, No. 1. Taxonomy and classification of the subfamily Lamiinae, tribes Parmenini through Acanthoderini. University of California Publications in Entomology 102:1-258.

Marinoni, R. C. 1972. Estudo monográfico do gênero Tapeina Lep. \& Serv., 1828 (Coleoptera, Cerambycidae). Boletim da Universidade Federal do Paraná (Zoologia) 5(1):1-76.

Marinoni, R. C.; Almeida, L. M.; NAPP, D. S. \& Rosado-Neto, G. H. 1992. Primeira lista do material-tipo de Coleoptera da coleção de Entomologia Pe. J. S. Moure, do Departamento de Zoologia da Universidade Federal do Paraná. Revista Brasileira de Zoologia 9(1-2):99-126.
Martins, U. R.; Galileo, M. H. M. \& Limeira-De-Oliveira, F. 2011 Cerambycidae (Coleoptera) do Estado de Maranhão, Brasil III. Papéis Avulsos de Zoologia 51(18):275-293.

Monné, M. A. 1994. Catalogue of the Cerambycidae (Coleoptera) of the Western Hemisphere. Part XIII. Subfamily Lamiinae: Tribes Parmenini, Moneilemini, Lamiini, Batocerini, Mesosini, Dorcaschematini, Phrynetini and Tapeinini. São Paulo, Sociedade Brasileira de Entomologia. 85p.

MonNÉ, M. A. 2005. Catalogue of the Cerambycidae (Coleoptera) of the Neotropical Region. Part II. Subfamily Lamiinae. Zootaxa 1023:1-759.

Monné, M. A. 2018. Catalogue of the Cerambycidae (Coleoptera) of the Neotropical region. Part II. Subfamily Lamiinae. Available at $<\mathrm{http}: / /$ cerambyxcat.com/>. Accessed on January 2019.

Monné, M. A. \& Giesbert, E. F. 1994. Checklist of the Cerambycidae and Disteniidae (Coleoptera) of the Western Hemisphere. Burbank, Wolfsgarden Books. 409p.

Monné, M. A. \& Hovore, F. T. 2006. A Checklist of the Cerambycidae, or longhorned wood-boring beetles, of the Western Hemisphere. Rancho Domingues, Bio Quip Publications. 393p.

Monné, M. A. \& MonNÉ, M. L. 2016. Checklist of Cerambycidae (Coleoptera) primary types of the Museu Nacional, Rio de Janeiro, Brazil, with a brief history of the collection. Zootaxa 4110(1):1-90.

Moura, L. De A. \& Groll, E. von. 2017. Catalogue of Coleoptera type specimens housed in the collection of the Museu de Ciências Naturais, Fundação Zoobotânica do Rio Grande do Sul, Brazil. Zootaxa 4318(3):439-473.

Nascimento, F. E. N.; Santos-Silva, A. \& Barclay, M. V. L. 2019. On the tribal allocation of Cosmotomidius Melzer, 1931, descriptions of new taxa of Acanthoderini and notes on some tribes of Lamiinae (Coleoptera, Cerambycidae). Journal of Natural History, in press.

PASCOE, F. P. 1864. Longicornia Malayana: or a descriptive catalogue of the species of the three longicorn families Lamiidae, Cerambycidae and Prionidae collected by Mr. A. R. Wallace in the Malay Archipelago. (Part I). The Transactions of the Entomological Society of London 3(3) 1:1-96.

SAMA, G. 2008. Preliminary note on the Cerambycid fauna of North Africa with the description of new taxa (Insecta, Coleoptera, Cerambycidae). Quaderno di Studi e Notizie di Storia Naturale della Romagna 27:217-245.

Santos-Silva, A. \& Nascimento, F. E. L. 2018. Synonymies, transferences, redescriptions and new species in Lamiinae (Coleoptera, Cerambycidae). Zootaxa 4462(2): 192-210.

Tavakilian, G. L. \& Chevillotte, H. 2018. Titan: base de données internationales sur les Cerambycidae ou Longicornes. Available at $<$ http://titan.gbif.fr/index.html >. Accessed on January 2019.

Thomson, J. 1857. Monographie du groupe des tapeinites, de la famille des cérambycides (longicornes). Archives Entomologiques 1:39-44.

Thomson, J. 1860. Essai d'une classification de la famille des cérambycides et matériaux pour servir a une monographie de cette famille. Paris, Bouchard-Huzard. 128p.

THOMson, J. 1864-1865. Systema cerambycidarum ou exposé de tous les genres compris dans la famille des cérambycides et familles limitrophes. Liége, H. Dessain. 578p. [1864: p. 1-352; 1865: p. 353-578].

Wappes, J. E.; Lingafelter, S. W.; MonNé, M. A. \& ARias, J. L. 2013. Additions to the known Vesperidae and Cerambycidae (Coleoptera) of Bolivia. Insecta Mundi 319:1-28.

Wappes, J. E.; Morris, R. F.; Nearns, E. H. \& Thomas, M. C. 2006. Preliminary list of Bolivian Cerambycidae (Coleoptera). Insecta Mundi 20(1-2):1-45.

ZAJCIW, D. 1974. Contribuição para o estudo da fauna dos longicórneos (Coleoptera, Cerambycidae) das florestas do Estado do Espírito Santo e principalmente da Reserva Biológica Soôretama. Boletim Técnico do Instituto Brasileiro de Desenvolvimento Florestal 4:37-91. 